В. П. Саганов и $\partial p$. Модифицированная коллаген-ламининовая матрица в лечении ожогово болезни. Клинический пример

УДК 617-089.844

DOI: 10.18101/2306-1995-2019-3-3-14

\title{
МОДИФИЦИРОВАННАЯ КОЛЛАГЕН-ЛАМИНИНОВАЯ МАТРИЦА В ЛЕЧЕНИИ ОЖОГОВОЙ БОЛЕЗНИ. КЛИНИЧЕСКИЙ ПРИМЕР
}

\section{(C) Саганов Владислав Павлович}

доктор медицинских наук, заместитель директора по лечебной работе

Бурятский государственный университет им. Д. Банзарова

Россия, 670002, г. Улан-Удэ, ул. Октябрьская, 36а

тел: 8(3012) 44-55-03

главный специалист по развитию хирургической помощи Республиканская клиническая больница имени Н. А. Семашко Россия, 670042, г. Улан-Удэ, просп. Строителей, 1

E-mail:vlad-saganov@yandex.ru

\section{(C) Бутуханов Сергей Борисович}

кандидат медицинских наук, заведующий, отделение гнойной хирургии,

Республиканская клиническая больница имени Н. А. Семашко Россия, 670042, Улан-Удэ, просп. Строителей, 1

тел: 8(3012) 55-62-74

старший преподаватель,

Бурятский государственный университет им. Д. Банзарова Россия, 670002, г. Улан-Удэ, ул. Октябрьская, 36а

тел: 8(3012) 44-55-03

E-mail: butukhanov_serg@mail.ru

\section{(C) Балханов Юрий Содномович}

генеральный директор,

МИП «Байкальский центр биотехнологий»

Россия, 670034, Улан-Удэ, ул. Хахалова, 6

тел: 8(3012) 55-21-41

E-mail: onohoi@inbox.ru

старший преподаватель,

Бурятский государственный университет им. Д. Банзарова

Россия, 670002, г. Улан-Удэ, ул. Октябрьская, 36а

тел: 8(3012) 44-55-03

E-mail: butukhanov_serg@mail.ru 


\section{(C) Башкуев Булат Романович}

ассистент,

Бурятский государственный университет им. Д. Банзарова

Россия, 670002, г. Улан-Удэ, ул. Октябрьская, 36а

тел: 8(3012) 44-55-03

врач-хирург,

Республиканская клиническая больница имени Н. А. Семашко

Россия, 670042, Улан-Удэ, проспект Строителей, 1

E-mail: bashkuev@inbox.ru

\section{(C) Хитрихеев Владимир Евгеньевич}

доктор медицинских наук, профессор, заведующий, кафедра госпитальной хирургии

Бурятский государственный университет им. Д. Банзарова

Россия, 670002, г. Улан-Удэ, ул. Октябрьская, 36а

тел: 8(3012)445503

E-mail: khitrikheev-ve@yandex.ru

Для цитирования:

Саганов В. П., Бутуханов С. Б., Балханов Ю. С., Башкуев Б. Р., Хитрихеев В. Е. Модифицированная коллаген-ламининовая матрица в лечении ожоговой болезни. Клинический пример // Вестник Бурятского государственного университета. Медицина и фармация. 2019. Вып. 3. C. $3-14$

Значительное улучшение результатов отделения гнойной хирургии ГАУЗ «РКБСМП им. В. В. Ангапова» в лечении обожженных стало возможно благодаря разработке и внедрению Байкальским центром биотехнологий модифицированной коллаген-ламининовой матрицы (аналог живой кожи) в клиническую практику. МИП «Байкальский центр биотехнологий» образован на базе медицинского центра «Диамед» и ФГБОУ ВО «Бурятский государственный университет им. Д. Банзарова». В состав аналога живой кожи входят биологически активные вещества коллаген и ламинин производные клеток кожи. Коллаген обладает и лечебным свойством. Ламинин воспроизводят клетки, которые затем ликвидируются. Ранозаживляющий материал по сравнению с аналогами не содержит чужеродные клетки, отличается простотой изготовления, длительностью срока хранения не менее 12 месяцев.

В исследуемой работе отражены положительные результаты лечения пациентов с последствиями термических травм в отделении гнойной хирургии БСМП им. В. В. Ангапова г. Улан-Удэ в 2018 г. Основой лечения являлась аллопластика с применением модифицированной коллагенламининовой матрицы.

Внедрение биотехнологических методов восстановления кожных покровов способствовало ускоренному выздоровлению пациентов с термической 
B. П. Саганов и $\partial p$. Модифицированная коллаген-ламининовая матрица в лечении ожогово болезни. Клинический пример

травмой и проведению более ранней реабилитации с последующим снижением инвалидизации.

Ключевые слова: коллаген, ламинин, живая кожа, термическая травма, аллопластика, биотехнологический метод, ранняя реабилитация.

\section{Введение}

Ожоги представляют глобальную проблему в области здравоохранения. В мире ежегодно происходит 195000 случаев смерти от ожогов [1]. На протяжении последних трех десятилетий частота ожогов во всем мире непрерывно возрастает. По данным Всемирной организации здравоохранения, термические поражения занимают третье место среди прочих травм [2]. Это объясняется высокой энерговооруженностью современного производства, транспорта, широким использованием токов высокого напряжения, агрессивных химических жидкостей и взрывоопасных газов. По данным отечественных авторов, ожоги формируют 8-12\% общего травматизма [3].

Несмотря на определенные успехи, достигнутые за последние годы в лечении пациентов с обширным ожогом, проблема термических поражений сохраняет свою актуальность. Необходимость дальнейшего изучения всех ее аспектов связана с тем, что число пострадавших от ожогов во всем мире, особенно в промышленно развитых странах, неуклонно растет, а результаты их лечения оставляют желать лучшего [4].

Основной целью при лечении обожженных пациентов является максимально быстрое восстановление целостности кожного покрова [5]. Однако при обширных глубоких ожогах, поражающих более $30 \%$ поверхности тела, возникает дефицит донорских ресурсов кожи и в совокупности с развитием осложнений травмы часто приводит к летальному исходу [6]. В связи с этим актуальность развития, область применения и процесс внедрения модифицированной коллаген-ламининовой матрицы в современные методы лечения высока, так как она не содержит человеческих клеток, тем самым не противоречат современному законодательству и в разы уменьшает риски развития осложнений, патологических реакций организма [7].

\section{Материал и методы}

Модифицированная коллаген-ламининовая матрица (аналог живой кожи) результат деятельности Байкальского центра биотехнологий, созданного на базе медицинского центра «Диамед» и Бурятского государственного университета им. Д. Банзарова.

Аналог «живой кожи» - это тонкая пленка, в основе которой лежат коллаген и ламинин. В состав данного продукта не входят донорские человеческие клетки. Представляет собой прозрачную желеобразную пленку различной величины, помещенную в чашку Петри (рис. 1). 


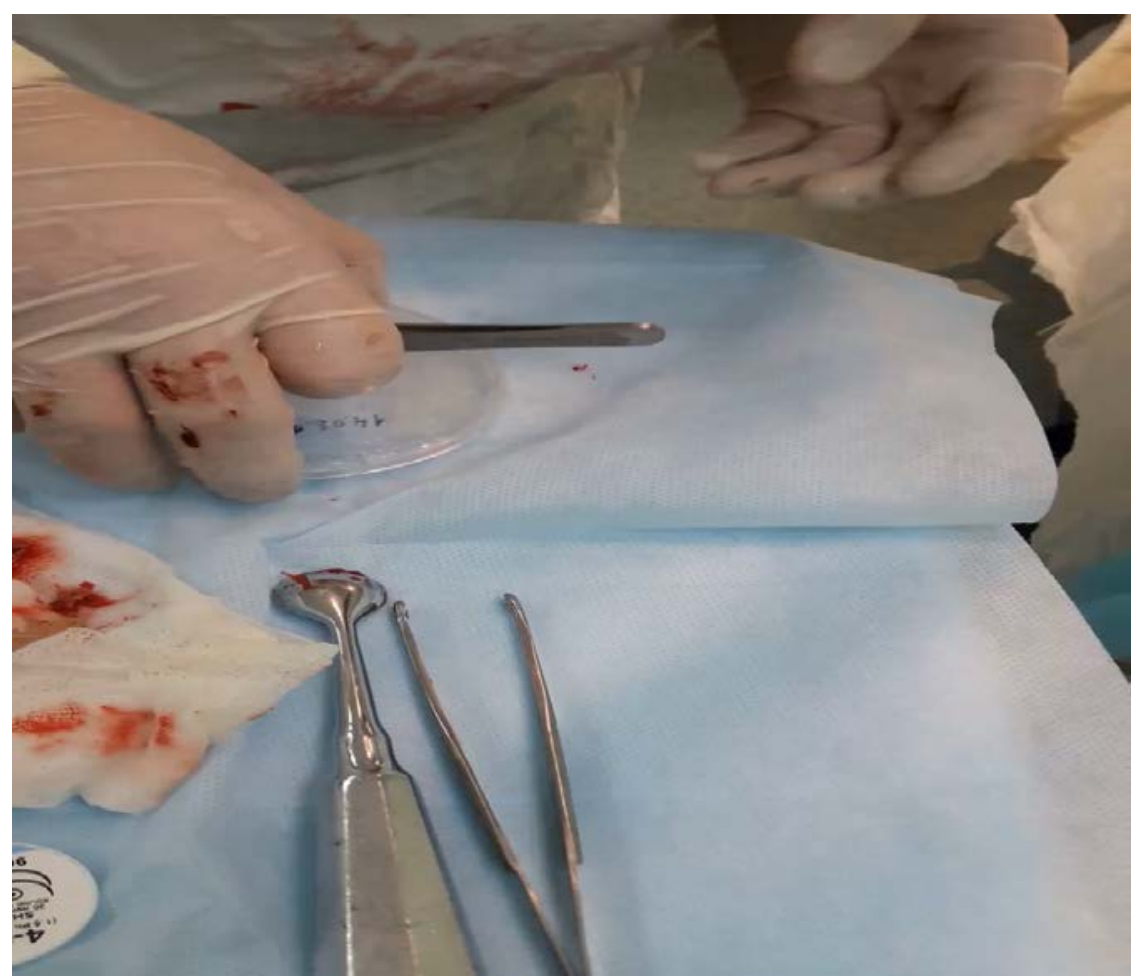

Рис. 1. Аналог «живой кожи» перед применением

Материалом аналога «живой кожи» служит соединительная ткань (сухожилия) лабораторных крыс. Коллаген - самый распространенный белок в нашем теле, основной компонент соединительных тканей, который в том числе входит в состав кожи. Коллаген выполняет ряд важных функций, включая обеспечение кожи структурой и упругостью. Ламинин, в свою очередь, стимулирует и ускоряет физиологический процесс заживления ран. Данный продукт может сохранять свои свойства до 12 месяцев. Материал может быть использован не только при лечении ожоговых ран, но и при отморожениях, трофических язвах, длительно незаживающих ранах, пролежнях.

Аллопластика модифицированной коллаген-ламининовой матрицей использована при лечении пациента с последствием термического ожога правого плеча и области плечевого сустава, полученного в июле 2018 г. и имевшего характер вялогранулирующих, длительно незаживающих постожоговых ран.

Материал хранился в соответствующих условиях, рекомендованных биотехнологами. Пациенту проводилась аллопластика «живой кожи» в условиях операционной и в связи с риском инфицирования проводилось ведение ран закрытым методом на протяжении от 2-х до 4-х суток. Максимальная площадь закрытия дефектов кожного покрова составила $3 \%$. 
B. П. Саганов и $\partial p$. Модифицированная коллаген-ламининовая матрица в лечении ожогово болезни. Клинический пример

\section{Результаты}

Пациент Г., 14.04.1965 г. р., поступил в ОГХ БСМП им. В. В. Ангапова с диагнозом: последствия термического ожога от июля 2018 г. Осложнения: Вялогранулирующие постожоговые раны правого плеча и области правого плечевого сустава.

Из анамнеза: пациент получил ожог кипятком в быту в июле 2018 г. Находился на лечении в ОГХ БСМП, где проводилось консервативное и оперативное лечение путем некрэктомии и аутодермопластики. Частично ожоговые раны имели признаки спонтанной эпителизации. Выписан на медицинскую паузу. В течение последних семи суток, перед повторной госпитализацией для этапного оперативного лечения, отмечаются повышение температуры тела и слабость.

Локально: в области плечевого сустава и правого плеча имелись постожоговые вялогранулирующие раны площадью до $3 \%$, с налетом фибрина и серозным отделяемым. Повторно госпитализирован в ОГХ для этапного оперативного лечения с целью закрытия оставшегося дефекта кожного покрова. Проводились:

- консервативное лечение (антибактериальная терапия: p-p Цефтриаксона 2,0 два раза, p-p Метрогила 100,0 три раза); инфузионная, обезболивающая и симптоматическая терапия, ежедневная санация раневой поверхности растворами антисептиков;

- оперативное лечение: 23.10 .18 г. — расширенная перевязка вялогранулирующих ран под общим обезболиванием; 24.10 .18 г. — пластика вялогранулирующих ран модифицированной коллаген-ламининовой матрицей. В послеоперационном периоде признаков лизиса аутотранплантата не было;

- бактериологические анализы раневого отделяемого в динамике: от 24.10.18 г. — enterobacter hormaechei-pseudomonasaeruginosa. Чувствительность к антибиотикам: амикацин-S, цефоперазон/сульбактам-S, цифтазидим-R, имипенем/циластатин-S, меропенем-S; от 26.10.18 г. — роста нет; от 29.10.18 г. enterobacter hormaechei 10^5: амикацин-S, ципрофлоксацин-R, цефотаксим-R, цефоперазон/сульбактам-S, цефтриаксон-R, цефепим-I, имипенем/циластатин-S, меропенем-S; от 30.10 .18 г. — acinetobacter baumannii 10^5-1; enterobacter cloacae ssp. 10^5-2: амикацин - 1-R, 2-S; ципрофлоксацин -1-R, 2-R; цефотаксим-2-R; цефоперазон/сульбактам - 1-R, 2-S; цефтриаксон - 2-R; цефепим-1-R; имипенем/циластатин - 1-R, 2-S; меропенем - 1-R, 2-S.

7 ноября 2018 г. после полного приживления трансплантанта пациент выписан на дальнейшее наблюдение и лечение у хирурга поликлиники по месту жительства. 


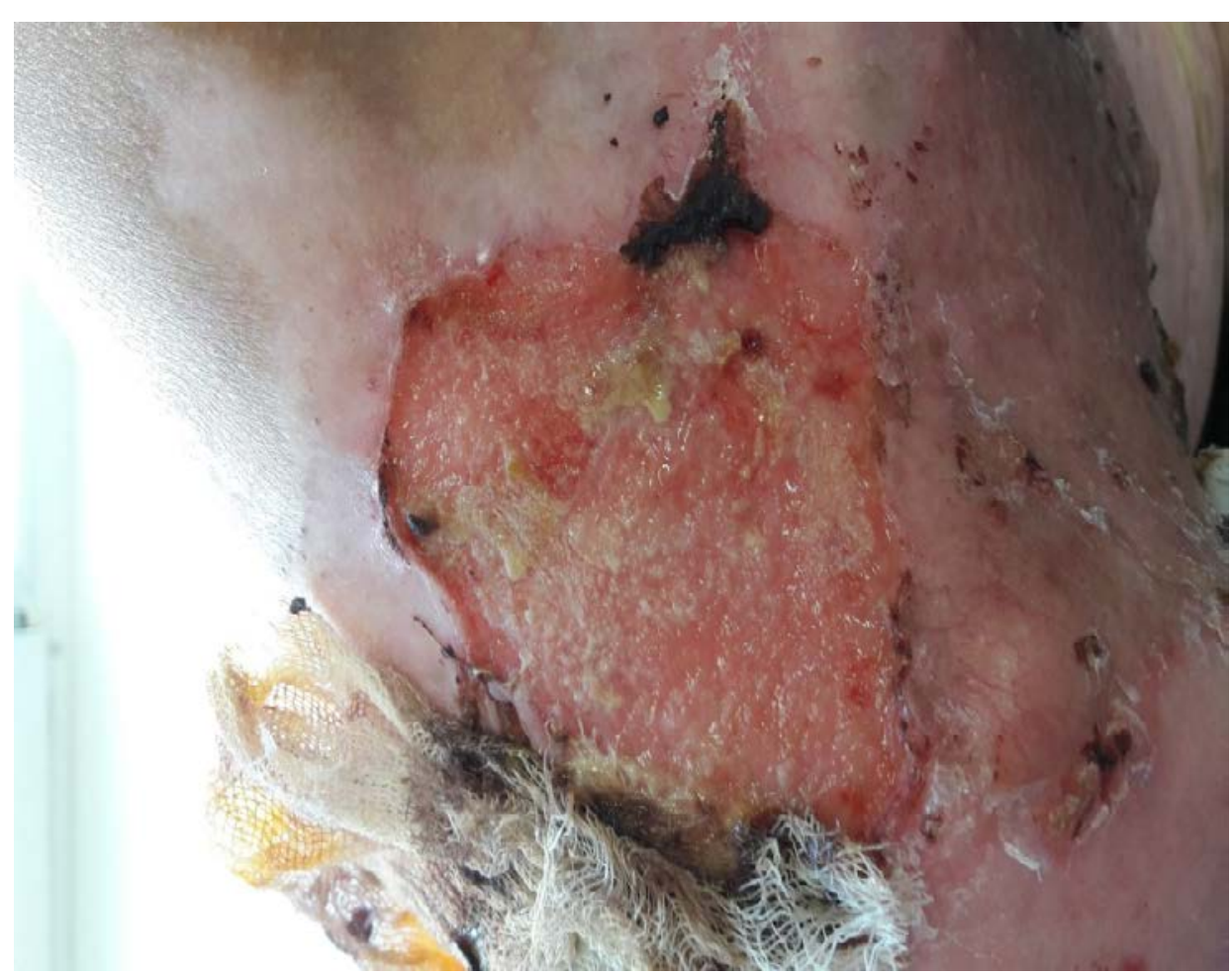

Рис. 1. Первые сутки после пересадки «живой кожи»

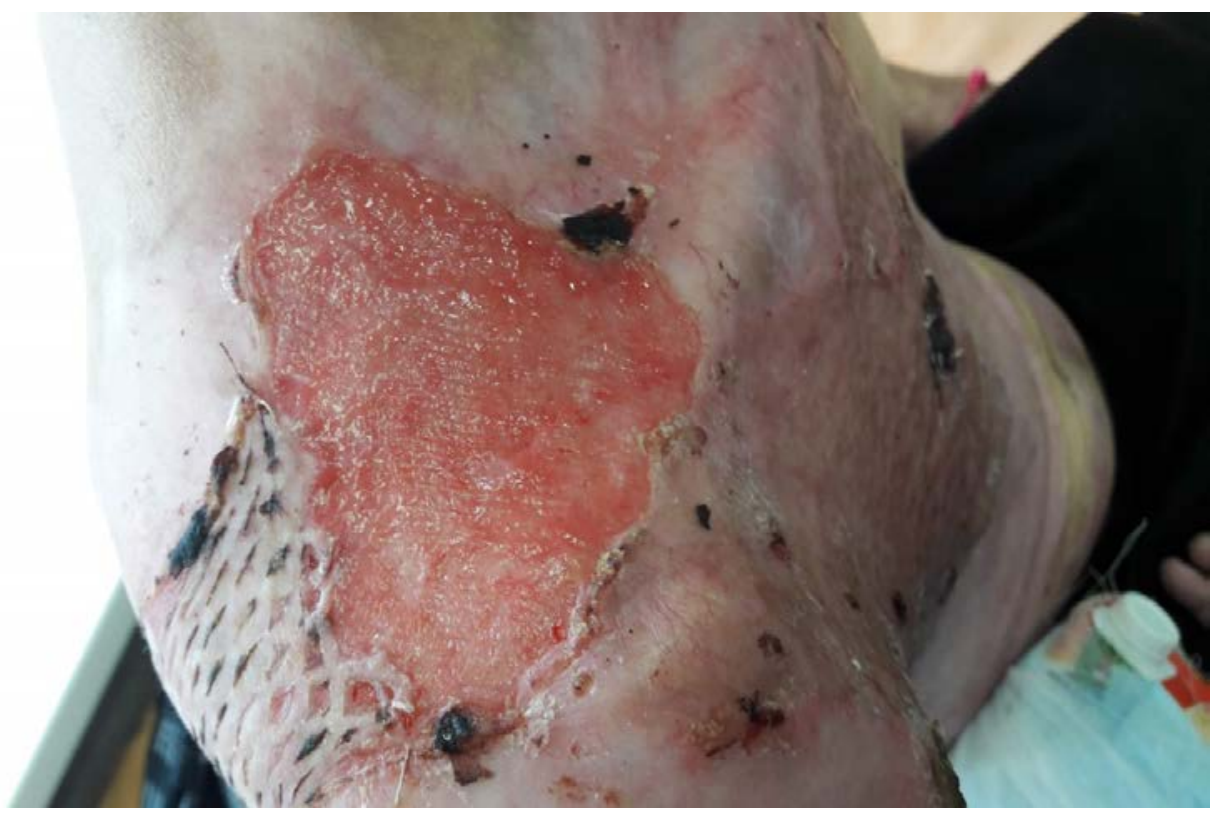

Рис. 2. Третьи сутки 
B. П. Саганов и др. Модифицированная коллаген-ламининовая матрица в лечении ожогово болезни. Клинический пример

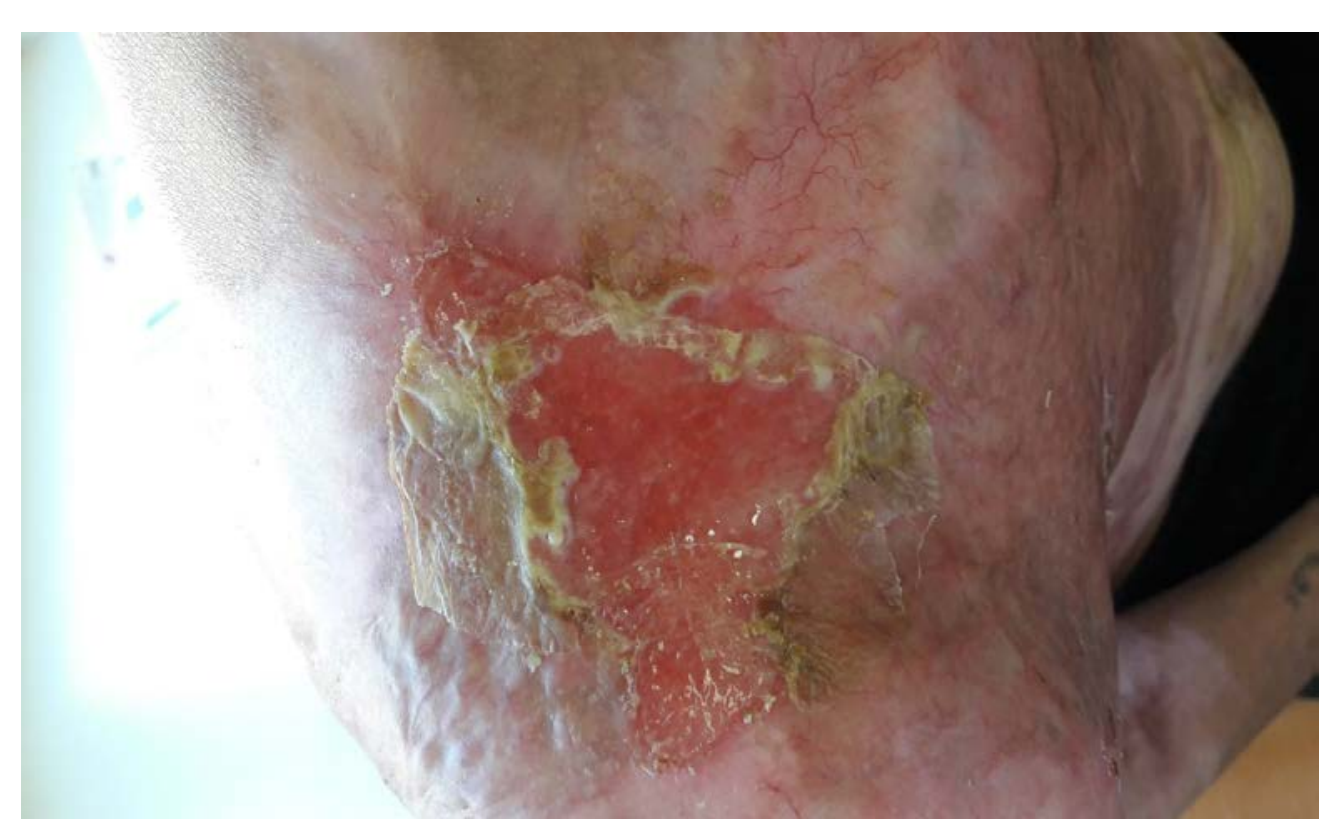

Рис. 3. Седьмые сутки

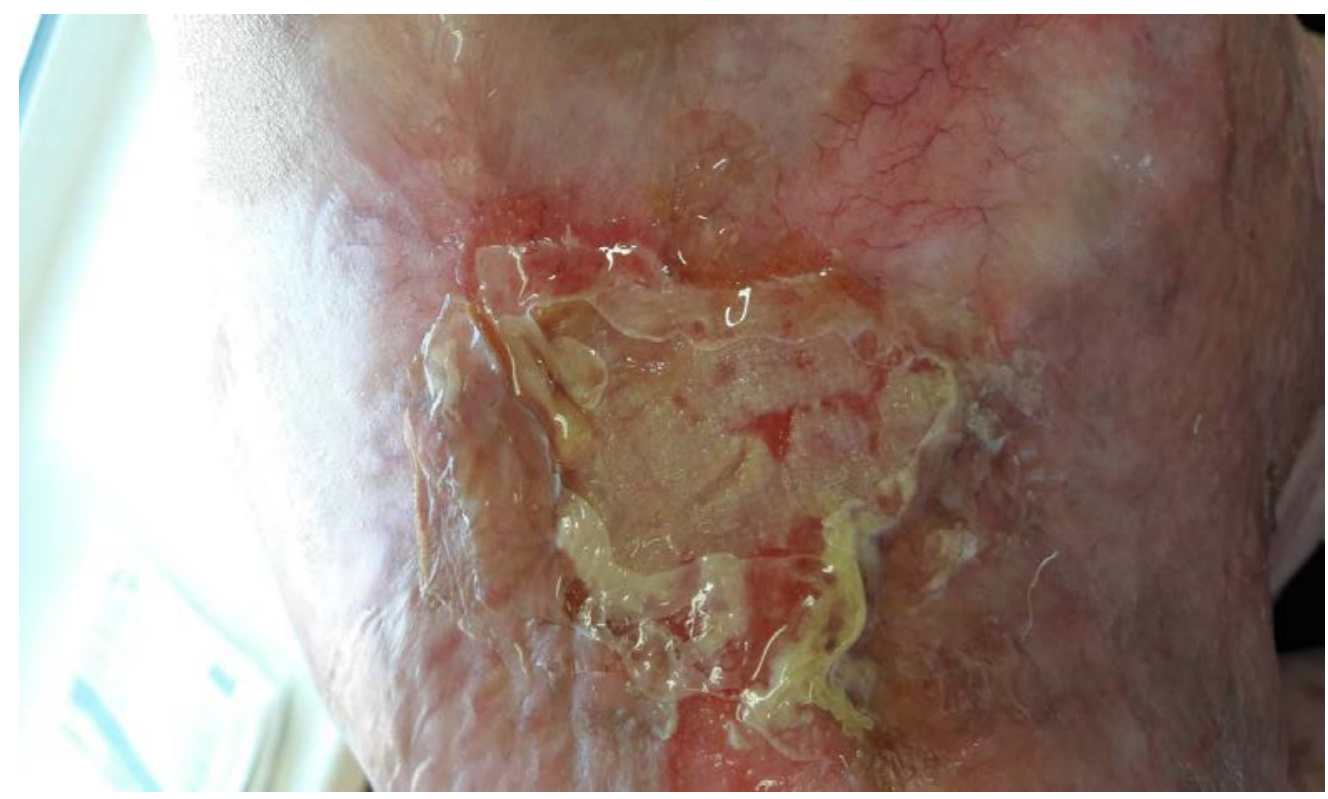

Рис. 4. Десятые сутки 


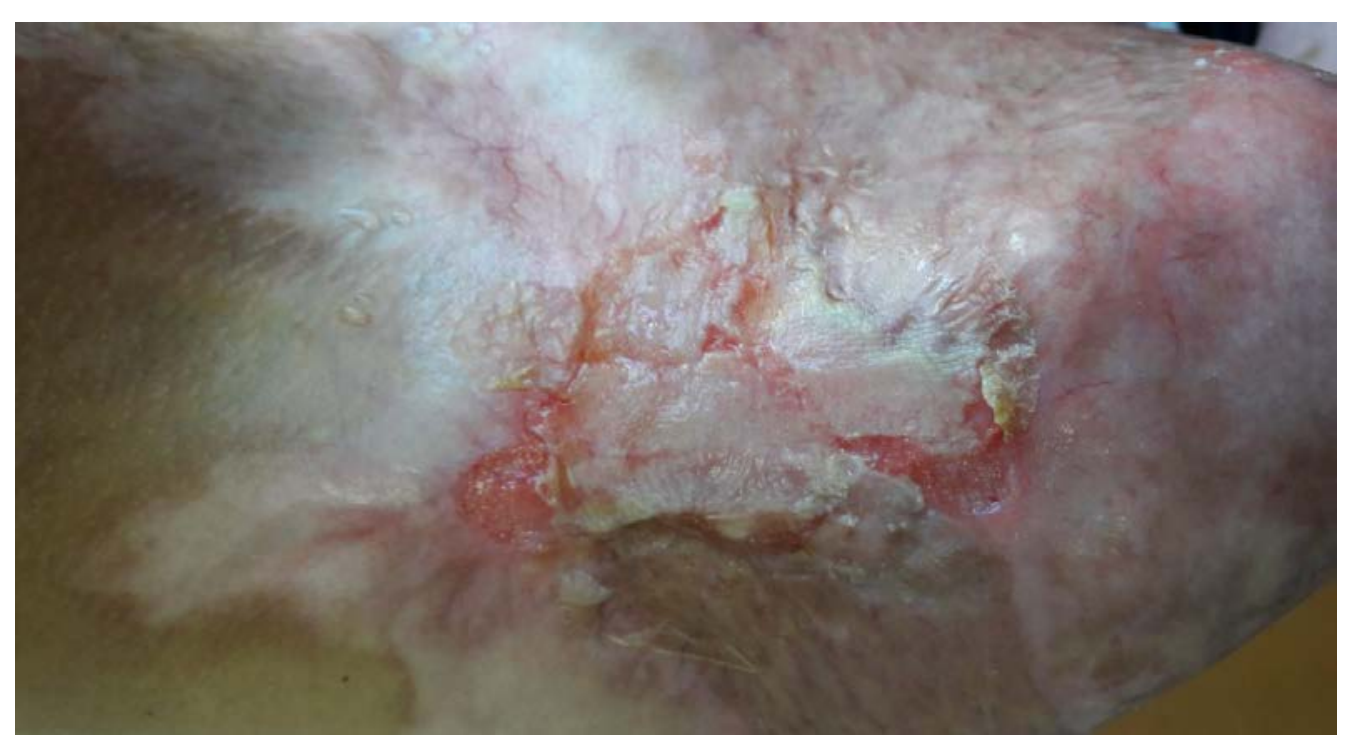

Рис. 5. Четырнадцатые сутки

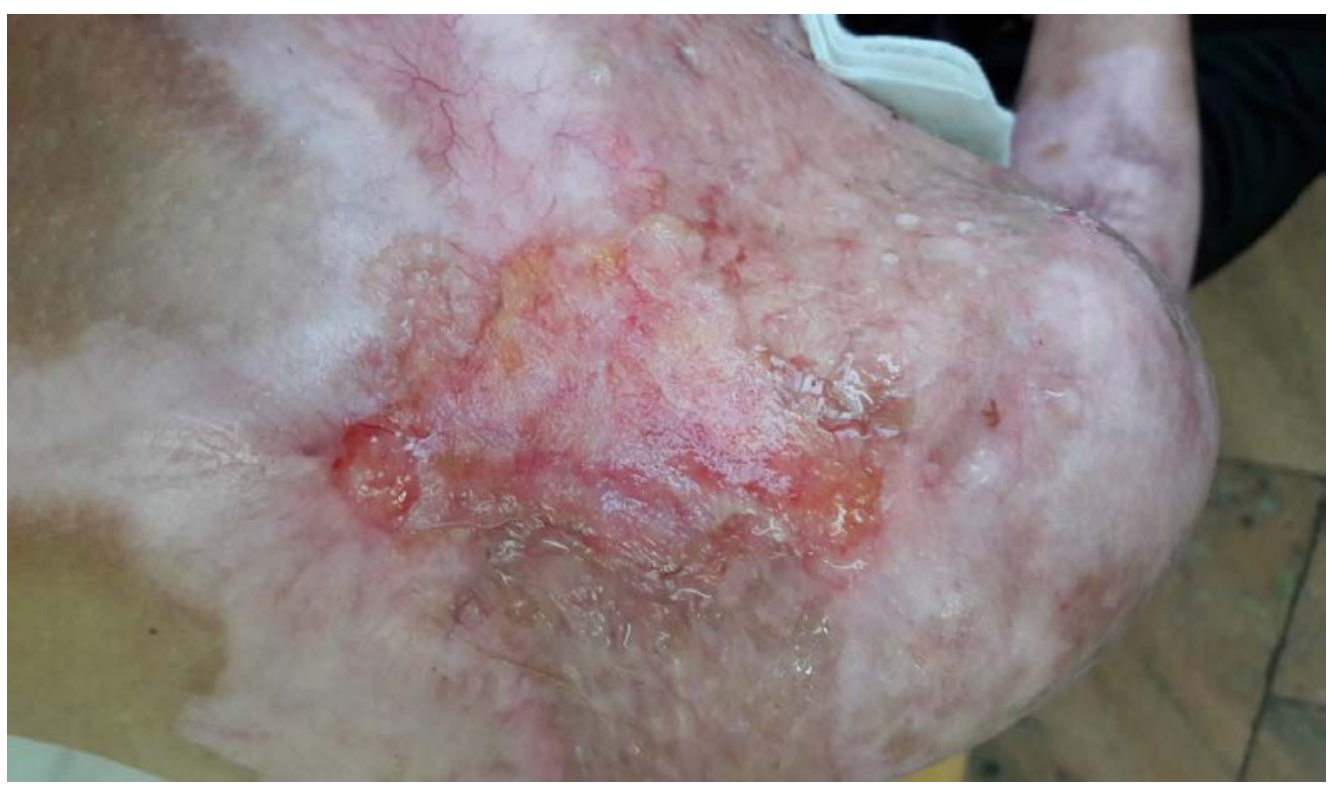

Рис. 6. Двадцатые сутки 
В. П. Саганов и др. Модифицированная коллаген-ламининовая матрица в лечении ожогово болезни. Клинический пример

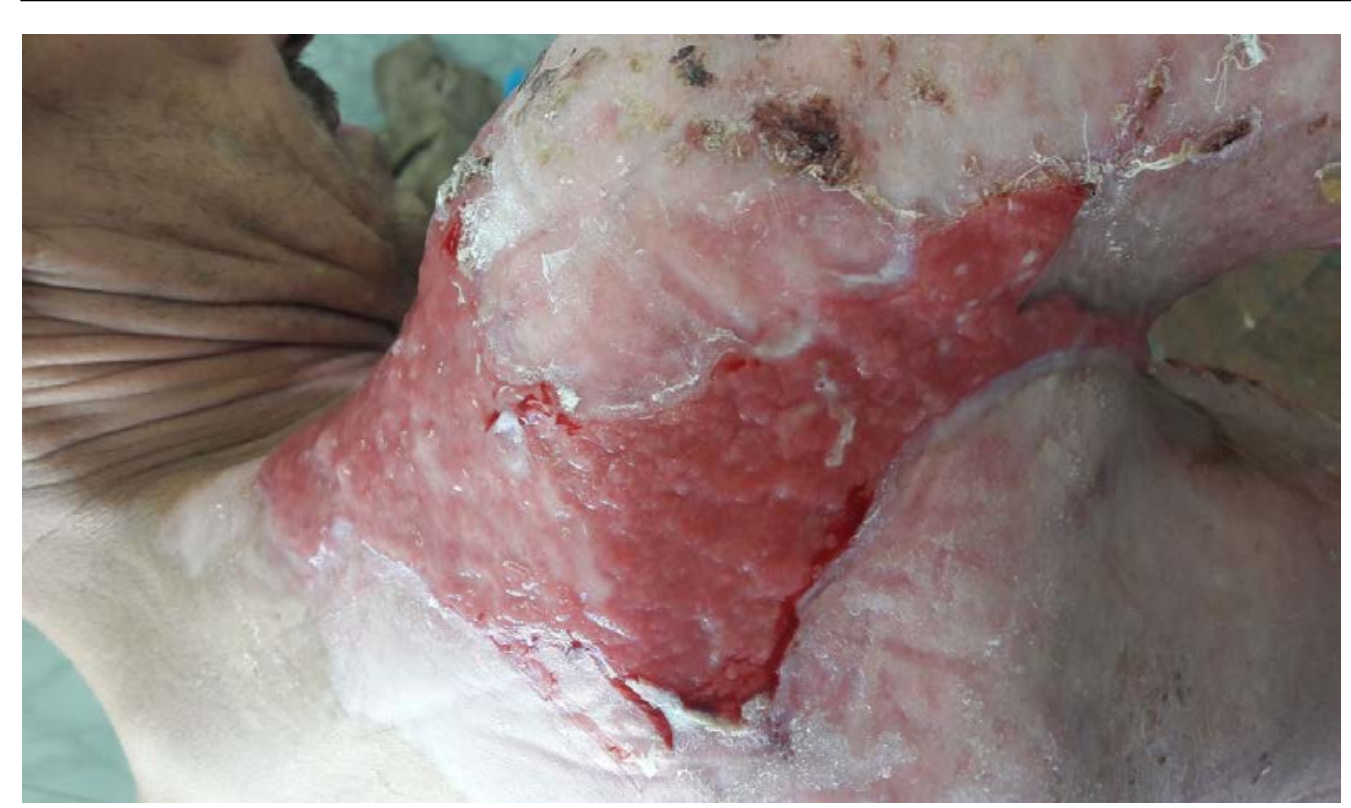

Рис. 7. Больной Г. в начале лечения

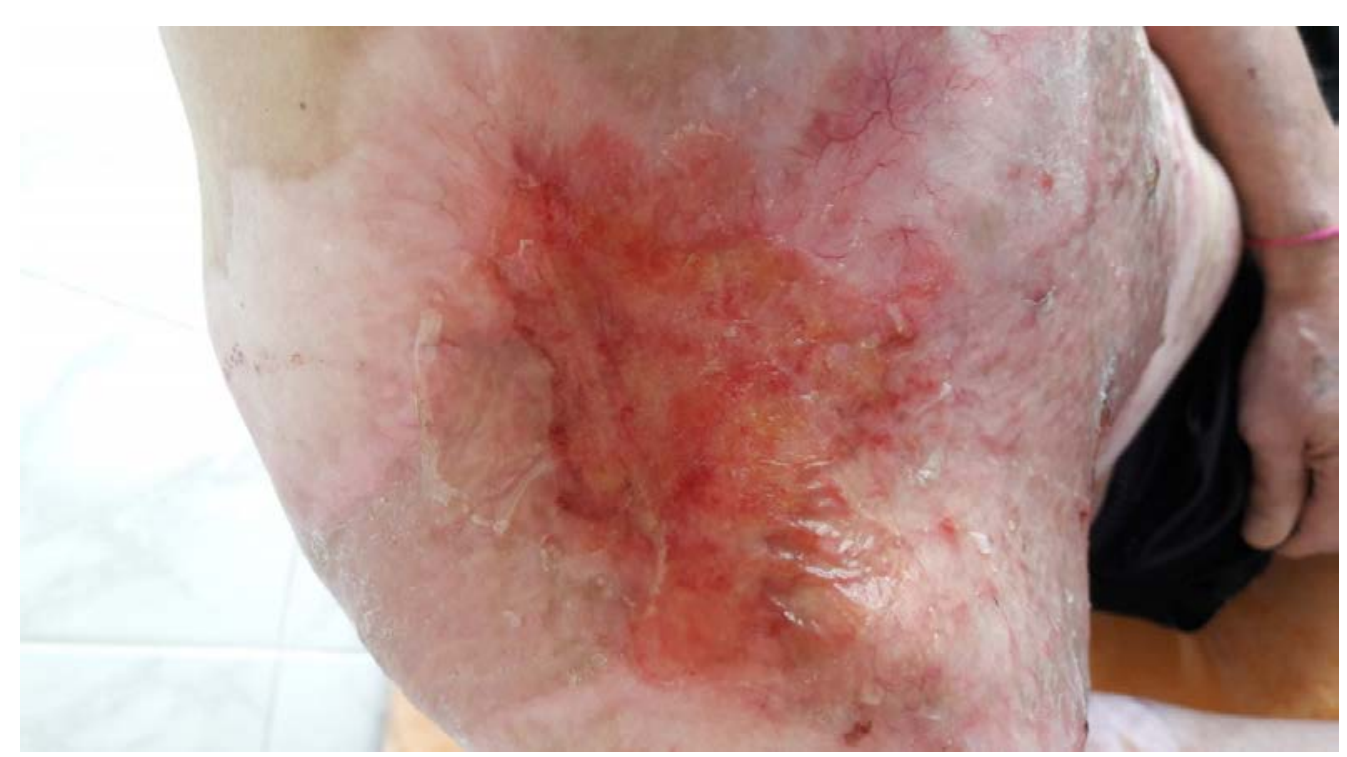

Рис. 8. В конце лечения

Через 6 недель результат оказался положительный.

Таким образом, при аллопластике модифицированной коллагенламининовой матрицей достигается более полное приживление, ускоряется краевая эпителизация даже в присутствии патогенной микрофлоры. Внедрение и совершенствование биотехнологических методов восстановления кожных 
покровов приведут к качественно новому уровню развития комбустиологии, что, несомненно, приведет к уменьшению смертности при тяжелых ожогах, уменьшению случаев инвалидизации, ускорению выздоровления и ранней реабилитации.

Лuтература

1. Абаев Ю. К. Биология заживления острой и хронической раны // Медицинские новости. 2003. № 6. С. 3-10.

2. Алексеева Н. Т., Глухов А. А., Остроушко А. П. Роль клеток фибропластического дифферона в процессе заживления ран // Вестник экспериментальной и клинической хирургии. 2012. Т. 5, № 3. С. 601-608.

3. Аничков И. П., Волкова К. Г., Гаршин В. Г. Морфология заживления ран. М.: Медгиз, 1951. 123 с.

4. Болдырев А. А., Кяыйвяряйнен Е. И., Илюха В. А. Биомембранология: учебное пособие для студентов высших учебных заведений, специализирующихся в области биологии, медицины и психологии. Петрозаводск: КНЦ РАН, 2006. 225 с.

5. Глухов А. А., Аралова М. В. Патофизиология длительно незаживающих ран и современные методов стимуляции раневого процесса // Новости хирургии. 2015. Т. 23, № 6. С. 673-679.

6. Клиническая хирургия: национальное руководство: в 3 т. / под ред. В. С. Савельева, А. И. Кириенко. М.: ГЭОТАР-Медиа, 2008. Т. 1. 864 с.

7. Копылов В. А., Никитенко И. Е. Применение фактора роста фибробластов в медицине // Вестник ОГУ. 2010. № 4. С. 95.

1. Abaev Yu. K. Biology of healing of acute and chronic wounds // Med. current events. 2003. №. 6. P. 3-10.

2. Alekseeva N. T., Glukhov A. A., Ostroushko A. P. The Role of fibroplastic differon cells in the process of wound healing // Vestn. Jim. and the wedge. surgeries. 2012. Vol. 5, № 3. P. 601-608.

3. Anichkov I. P., Volkova K. G., Garshin V. G. Morphology of wound healing. M.: Medgiz, 1951. $123 \mathrm{p}$.

4. Boldyrev A. A., Kaivarainen E. I., Ilyukha V. A. Biomembrane: proc. manual for University students. studies'. institutions specializing in the field of biology, medicine and psychology. Petrozavodsk: Karelian research centre, RAS, 2006. 225 p.

5. Glukhov A. A., Aralova M. V. Pathophysiology of long-term non-healing wounds and modern methods of stimulation of wound process // News of surgery. 2015. Vol. 23, № 6. P. 673-679.

6. Clinical surgery: a national. hands': in 3 pt. / ed. V. S. Savelyev, A. I. Kiriyenko. Moscow: GEOTAR-Media, 2008. T. 1. 864 c.

7. Kopylov V. A., Nikitenko I. E. Application of fibroblast growth factor in medicine // Vestn. OSU. 2010. № 4. P. 95. 
В. П. Саганов и др. Модифицированная коллаген-ламининовая матрица в лечении ожогово болезни. Клинический пример

\section{MODIFIED COLLAGEN-LAMININ MATRIX \\ IN THE TREATMENT OF BURN DISEASE. CLINICAL EXAMPLE}

\section{Vladislav P. Saganov}

Doctor of Medical Sciences

Deputy Director for Medical Work of the Medical Institute

Dorzhi Banzarov Buryat State University

36a Oktyabrskaya st., Ulan-Ude, 670002, Russia

Tel: +7(3012) 448255

Chief Specialist in the Development of Surgical Care

GAU RK BSMP named after V. V. Angapova

1, Prospect Stroitelei, Ulan-Ude, 670042, Russia

Tel: +7(3012) 556274

E-mail: vlad-saganov@yandex.ru

Sergey B. Butukhanov

Candidate of Medical Sciences

Head of the Department of Purulent Surgery,

GAU RK BSMP named after V. V. Angapova

1, Prospect Stroitelei, Ulan-Ude, 670042, Russia

Tel: +7(3012) 556274

Senior Lecturer of the Medical Institute

Dorzhi Banzarov Buryat State University

36a Oktyabrskaya st., Ulan-Ude, 670002, Russia

E-mail:butukhanov_serg@mail.ru

Yuri S. Balkhanov

General Director of MIP "Baikal Center of Biotechnology"

6, Khakhalova st., Ulan-Ude, 670034

Tel: +7 (3012) 552141,

E-mail: onohoi@inbox.ru

Bulat R. Bashkuev

Surgeon of the Surgical Department of

GAU RK BSMP named after V. V. Angapova

1, Prospect Stroitelei, Ulan-Ude, 670042, Russia

Tel: +7(3012) 556274

Assistant of the Department of Hospital Surgery of the Medical Institute

Dorzhi Banzarov Buryat State University

36a Oktyabrskaya st., Ulan-Ude, 670002, Russia

E-mail:bashkuev@inbox.ru

Vladimir E. Khitrikheev

Doctor of Medical Sciences

Head of the Department of Hospital Surgery of the Medical Institute

Dorzhi Banzarov Buryat State University

36a Oktyabrskaya st., Ulan-Ude, 670002, Russia

Tel: +7(3012) 448255

E-mail: khitrikheev-ve@yandex.ru 
A significant improvement in the results of treating the burned in the Department of Purulent Surgery GAU "RK BSMP V. V. Angapova", became possible due to the development and implementation of MIP "Baikal center of biotechnology" in the clinical practice of Modified collagen-laminin matrix (analogue of "natural skin"). MIP "Baikal center of biotechnology" was formed through the joint work of the medical center "Diamed" and Buryat State University named after D. Banzarov. The composition of the analogue of the natural skin has biologically active substances-derivatives of skin cells: collagen and laminin. Collagen has a therapeutic factor. Laminin reproduces cells, which are then eliminated. The wound-healing material, in comparison with analogues, does not contain foreign cells, it differs in comparative simplicity of production and duration of storage - not less than 12 months.

The study presents positive results of treatment of patients with the consequences of thermal injuries in the Department of Purulent Surgery GAU RK BSMP named after V. V. Angapova, Ulan-Ude in 2018. The basis of treatment was alloplasty using a modified collagen-laminin matrix. The introduction of biotechnological methods of skin restoration allowed accelerated recovery of patients with thermal trauma and earlier rehabilitation with subsequent reduction of disability.

Keywords: collagen, laminin, natural skin, thermal trauma, alloplastika, biotechnological method, early rehabilitation. 